удК 346.91

DOI https://doi.org/10.32837/apdp.v0i85.1868

Н.О. Петренко

\title{
ЩОДО ЗАПРОВАДЖЕННЯ ЕЛЕКТРОННОГО ПРАВОСУДДЯ ПРИ ВИРІШЕННІ ГОСПОДАРСЬКИХ СПОРІВ
}

Постановка проблеми. Постановою Кабінету Міністрів України від 11 березня 2020 року № 211 «Про запобігання поширенню на території України гострої респіраторної хвороби COVID-19, спричиненої коронавірусом SARS-CoV-2» запроваджено всеукраїнський карантин строком з 12 березня 2020 року до 11 травня 2020 року. На підставі цієї постанови Радою суддів України напрацьовані рекомендації для судів всіх ланок щодо зменшення кількості судових засідань в день, подання клопотань про розгляд справ за відсутності сторін провадження або у письмовому провадженні тощо. 3 метою запобігання поширенню гострих респіраторних захворювань і коронавірусу COVID-19 більшість судів обмежили доступ учасників судових процесів та громадян до приміщень судів.

Радою суддів України та Вищою радою правосуддя були надані лише рекомендації для судів по роботі в умовах карантину. Отже, суди залишилися в ситуації самовизначення організації подальшої роботи. Тому й постало питання подальшого відправлення правосуддя. До того ж обмеження транспортного сполучення між населеними пунктами, введення обмежень при користуванні міським транспортом, закриття окремих населених пунктів і рекомендації по самоізоляції населення призвели до актуалізації та необхідності вирішення питань, пов'язаних із доступом громадян до правосуддя в умовах карантину. Якщо раніше питання дистанційного правосуддя, проведення судових засідань в режимі відеоконференції, здійснення документообігу між судами та учасниками судового провадження в електронному вигляді носили другорядний характер, то в обмежувальних умовах зазначені питання почали розглядатися в ракурсі реалізації принципу доступу осіб до правосуддя.

Метою статті $є$ дослідження проблеми впровадження електронного правосуддя в господарських судах України, його позитивні та негативні риси.

Виклад основного матеріалу. Спеціалізовані суди (господарські та адміністративні) одні з перших відреагували на рекомендації Ради суддів України та Вищої ради правосуддя щодо запровадження карантинних обмежень. Так, наказом голови Господарського суду Херсонської області від 18.03.2020 суддям по можливості було запропоновано зменшити кількість судових засідань, які призначаються для розгляду протягом робочого дня, та здійснювати судовий розгляд справ без участі сторін в порядку письмового провадження [1]. Вже 20 березня 2020 року збори суддів Господарського суду Херсонської області вирішили припинити допуск осіб до приміщення суду, крім працівників суду, представників підрозділу військової частини № 3056 Національної гвардії України, працівників правоохоронних, аварійно-рятувальних органів та медичних закладів при виконанні ними професійних обов'язків на час дії карантинних заходів [2]. Господарський суд м. Києва 
продовжив призначення та розгляд справ із застосуванням дистанційних засобів і відеоконференцій з використанням програмного забезпечення: програми Microsoft Teams i Skype.

На день запровадження карантинних обмежень судова система господарських судів опинилася в ситуації обмеженого доступу громадян до приміщень судів, численних перенесень судових засідань, що призвело до збільшення строків розгляду справ, зменшення кількості призначених справ до розгляду тощо. Отже, в умовах соціального дистанціювання та численних обмежень одним із найважливіших питань, яке постає в судовій сфері, $є$ функціонування судів і відправлення правосуддя.

Впровадження дистанційного правосуддя не $є$ новим питанням, але воно набуло актуальності в усьому світі в результаті розповсюдження пандемії. Виключенням не $€$ й Україна. Однієюз основних переваг діяльності ланки господарських судів $є$ швидкість розгляду справ та суворе дотримання строків їх розгляду. Так, суб’єкти господарювання та інші особи, які звертаються до господарських судів, впевнені, що їх справабудерозглянутаіздотриманнямстроків, визначених чиннимзаконодавством. Проте із введенням обмежень та численними переносами справ господарські суди втрачають свою ефективність, хоча в умовах загострення економічної ситуації швидкість вирішення господарський спорів набуває ще більшої необхідності.

3 огляду на наведене вбачається, що головним викликом, який стоїть перед судовою системою, є запровадження електронного правосуддя. Один із його елементів - проведення судових засідань в режимі відеоконференції - успішно застосовується в господарському судочинстві вже тривалий час.

Так, Законом України «Про внесення змін до деяких законодавчих актів України щодо участі у судовому засіданні в режимі відеоконференції з 12 березня 2020 року до 11 травня 2020 року» від 04.07.2012 попередню редакцію ГПК України доповнено ст. 74-1, якою закріплено право участі в судовому засіданні в режимі відеоконференції. В подальшому Законом України «Про внесення змін до Господарського процесуального кодексу України, Цивільного процесуального кодексу України, Кодексу адміністративного судочинства України та інших законодавчих актів» від 03.10.2017 була прийнята нова редакція ГПК України, яка зберегла раніше закріплене право на участь в судових засіданнях у режимі відеоконференції (ст. 197 ГПК України).

Наведеним нормативно-правовим актом було запроваджено початок функціонування Єдиної судової інформаційно-телекомунікаційної системи (далі - ССITC) (ст. 6 ГПК України). Ч. 2 ст. 197 ГПК України врегульовано, що учасники справи беруть участь у судовому засіданні в режимі відеоконференції поза межами приміщення суду з використанням власних технічних засобів та електронного цифрового підпису згідно з вимогами Положення про Єдину судову інформаційно-телекомунікаційну систему [3].

Наказом Державної судової адміністрації України від 07 листопада 2019 року № 1096 затверджено Концепцію побудови ЄСІТС. Система має стати глобальною мережею, яка об’єднає електронний кабінет користувача, Єдиний державний реєстр судових рішень і виконавчих документів та інше. Вона повинна була запрацювати в Україні з 01 березня 2019 року, проте її запуск було відтерміновано. Так, 01 бе- 
резня 2019 року в офіційному виданні ВРУ «Голос України» було опубліковано оголошення про відкликання ДСА України повідомлення, яке опубліковано в газеті «Голос України» (№ 229 (6984) від 01.12.2018) щодо створення та забезпечення функціонування Єдиної судової інформаційно-телекомунікаційної системи [4].

Відповідно до ч. 6. ст. 6 ГПК України адвокати, нотаріуси, приватні виконавці, арбітражні керуючі, судові експерти, державні органи, органи місцевого самоврядування та суб'єкти господарювання державного та комунального секторів економіки реєструють офіційні електронні адреси в Єдиній судовій інформаційно-телекомунікаційній системі в обов'язковому порядку. Отже, ЄCITC має стати тією системою, яка започаткує повноцінну роботу електронного правосуддя в національній судовій системі. Так, фактично з'явиться можливість звернення до суду шляхом подання документів через Електронний суд, обміну документами між учасниками процесу, учасниками процесу та судом за допомогою інформаційнотелекомунікаційної системи, участі в судовому засіданні в режимі відеоконференції з власного робочого місця тощо. Саме концепція впровадження ЄCITC є базою, необхідною для роботи електронного правосуддя.

Вважаю, що саме ланка господарських судів може стати майданчиком для перших кроків в напрямі введення в дію електронного правосуддя. Так, більшість учасників судових спорів - це суб'єкти господарювання або органи, установи, які поступово долучаються до процесів діджиталізації в країні: запровадження електронних форм звітування, користування послугами он-лайн банків, можливість отримання дозвільних та інших документів безконтактним шляхом та їх обробка, електронний документообіг між контрагентами тощо. Серед переваг введення електронного правосуддя при вирішенні господарських спрів вважаю за необхідне виділити такі:

1) створення єдиної системи електронного документообігу. При цьому формування єдиної електронної судової справи, яка буде доступна не тільки судді, а i всім сторонам судового процесу, дозволить розширити та вдосконалити реалізацію принципу змагальності сторін;

2) розвиток взаємодії між судом та органами влади, місцевого самоврядування, органами примусового виконання судових рішень. Наведене дозволить зробити більш ефективною останню стадію судового процесу - виконання судового рішення;

3) скорочення строків вирішення спрів і зменшення витрат, пов'язаних із розглядом справи, які передані на розгляд до господарського суду. Так, електронний документообіг дозволить сторонам по справі та суду більш швидко отримувати документи, відповідно скоротиться і час розгляду справи, що зробить діяльність господарських судів ще ефективнішою. Що стосується витрат, то сторони по справі та інші учасники з використанням технологій електронного правосуддя зменшать свої витрати на поштовий зв’язок і прибуття до зали судового засідання.

Після запровадження карантинних обмежень на території України перспективи впровадження дистанційного правосуддя обговорювалися на чисельних онлайн майданчиках. Так, одним із недоліків, на яких наголошували експерти, є недотримання принципу гласності при застосуванні технологій електронного судочинства, але такі застереження не були обгрунтовані. Гласність судового процесу полягає в тому, що будь-яка особа має право бути присутньою у відкритому судовому засі- 
данні. Електронне правосуддя та розгляд справ в режимі відеоконференцій не означає, що судові засідання будуть закритими, а будь-яка особа не зможе бути присутньою при розгляді справи. Так, суд зможе забезпечити долучення до відеоконференції інших осіб, які виявлять бажання бути присутніми і матимуть таку технічну можливість. При цьому електронне правосуддя є лише одним зі способів відправлення правосуддя та не відміняє розгляд справи у приміщенні суду. Тому резонансні справи, справи з великою кількістю учасників або складні справи мають розглядатися в залах судового засідання.

Окремої уваги потребує питання термінології. Так, нині набув широкого застосування термін «дистанційне правосуддя». Проте застосування цього терміну є не коректним і може застосовуватися тільки під час характеристики проведення судових засідань в режимі відеоконференцій. Електронне правосуддя складається з комплексу систем, які забезпечать сторонам та суду проведення судового процесу з використанням інформаційних технологій (електронних кабінетів, електронного цифрового підпису, єдиних реєстрів, вебпорталів тощо).

Наведене підтверджується визначенням електронного правосуддя, яке закріплено в Рекомендації CM/Rec (2009) 1 KM PЄ державам-членам від 18 лютого 2009 року. Зокрема, відповідно до п. 38 зазначених Рекомендацій «електронне правосуддя - це використання IКТ (інформаційних та комунікаційних технологій) при відправленні правосуддя всіма зацікавленими сторонами в юридичній сфері з метою підвищення ефективності та якості державних служб, зокрема для приватних осіб та підприємств, що включає в себе електронний зв'язок і обмін даними, а також доступ до судової інформації» [5].

Висновки. Підсумовуючи наведене, можна зазначити, що розвиток електронного правосуддя при розгляді господарських справ має стати одним із пріоритетних напрямів реформування судової системи. Надання можливості сторонам та суду комунікувати за допомогою електронних технологій зробить господарське судочинство ще більш швидким та ефективним. При цьому учасники господарських відносин отримають новий засіб для захисту своїх порушених прав. До того ж електронне судочинство може стане новим каналом комунікації сторін спору та суду, що зробить суд більш доступним.

\section{Jimepamypa}

1. Наказ голови Господарського суду Херсонської області від 18 березня 2020 року. Посилання: https://ks.arbitr.gov.ua/sud5024/pres-centr/news/911369/.

2. Рішення зборів суддів Господарського суду Херсонської області від 20 березня 2020 року. Посилання: https://ks.arbitr.gov.ua/sud5024/pres-centr/news/913790/.

3. Господарський процесуальний кодекс України : Закон України. Посилання: https://zakon.rada. gov.ua/laws/show/1798-12\#n3030.

4. Оголошення Державної судової адміністрації України // Голос України. № 42 (7048). С. 1.

5. Рекомендації CM/Rec (2009) $1 \mathrm{KM}$ P€ державам-членам від 18.02.2009. Режим доступу: http://www.coe.int/t/dgap/democracy/Activities/GGIS/CAHDE/2009/RecCM2009_1_and_Acomp_ Docs/Recommendation\% 20CM_Rec(2009)1E_FINAL.asp\#TopOfPage. 


\section{Анотація}

Петренко Н. О. Щодо запровадження електронного правосуддя при вирішенні господарських спорів. - Стаття.

Швидкий та ефективний розгляд справ господарськими судами є однією з основних переваг діяльності ланки господарського судочинства. Проте із запровадженням карантинних обмежень на всій території України органи судочинства не стали винятком та обмежили доступ громадян до приміщень судів. Проте попри будь-які обмеження суди не можуть повністю зупинити свою діяльність. Тому набуло актуальності питання впровадження електронного правосуддя.

Досліджуване питання не є новим для України. Так, нова редакція Господарського процесуального кодексу України та інших процесуальних кодексів, прийнята в 2017 році, започаткувала введення в Україні безконтактного розгляду справ. Платформою, яка має забезпечити можливості дистанційного розгляду справ, стала Єдина судова інформаційно-телекомунікаційна система, але день її введення в дію відтерміновано.

Саме введення карантинних обмежень та обговорення можливостей щодо декількох хвиль розповсюдження коронавірусної хвороби вивело досліджуване питання на одне з головних місць. При цьому юридична спільнота вже тривалий час користується окремими елементами електронного правосуддя: участь в судових засіданнях в режимі відеоконференції, направлення документів до суду з електронним цифровим підписом, користування порталом Судова влада України тощо.

З урахуванням можливостей, які отримує суд та учасники судового процесу при використанні інструментів безконтактного спілкування, у статті наведені позитивні риси запровадження електронного правосуддя в України. До таких рис можна віднести створення єдиної системи електронного документообігу; розвиток взаємодії між судом та органами влади, місцевого самоврядування, органами примусового виконання судових рішень; скорочення строків вирішення спорів і зменшення витрат, пов'язаних із розглядом справ, які передані на розгляд до господарського суду. Тому електронне правосуддя має великі перспективи та можливості, які дозволять зробити суд більш доступним для сторін спору.

Ключові слова: електронне правосуддя, дистанційне правосуддя, Єдина судова інформаційнотелекомунікаційна система, участь у судовому засіданні в режимі відеоконференції, господарське судочинство.

\section{Summary}

Petrenko N. O. On the introducing of e-justice in resolving commercial disputes. - Article.

Prompt and effective consideration of cases by commercial courts is one of the main advantages of commercial litigation. However, with the introduction of quarantine restrictions throughout Ukraine, the judicial authorities were no exception and restricted citizens' access to the court premises. However, despite any restrictions, the courts cannot cease their activities completely. Thus, the issue of introduction of remote justice has become significantly relevant.

It should be noted that the question under study is not new for Ukraine. Thus, a new version of the Commercial Procedure Code of Ukraine and other procedural codes, adopted in 2017, introduced the introduction of contactless proceedings in Ukraine. The Unified Judicial Information and Telecommunication System has become a platform that should provide opportunities for remote consideration of cases. However, as of today, its introduction into effect has been postponed.

It was the introduction of quarantine restrictions and the discussion of the possibility of several waves of coronavirus disease that brought the research issue to one of the main points. At the same time, the legal community has been long used certain elements of remote justice, namely participation in court hearings using videoconference, sending documents to court with an electronic digital signature, the portal Judiciary of Ukraine and more.

Taking into account the opportunities provided by the court and the participants in the trial, when using the tools of contactless communication, the article presents the positive features of the introduction of electronic justice in Ukraine. Such features include the creation of a single electronic document management system; development of interaction between the court and authorities, local self-government, enforcement bodies; reducing the time for resolving cases and reducing the costs associated with the case, which are referred to the commercial court. Thus, remote justice has great prospects and opportunities that will make the court more accessible to the parties to the dispute.

Key words: e-justice, usticeremote justice, Unified Judicial Information and Telecommunication System, participation in a court hearing using videoconference, commercial litigation. 